\title{
The role of the cash flow statement to provide accounting information for the financial decision-making process
}

(Case study International Islamic Bank of Kurdistan in the year 2018)

\section{Hakar Abubakir bayz}

Department of Technical Accounting, Technical College of administration, Sulaimani polytechnic university, sulaimani, Kurdistan Region, Iraq

Hakar.abubakir@spu.edu.iq

\section{Diary Jalal Ali}

Department of Management (Technology), Faculty of Management and Social Science, Qaiwan International University, Sulaymaniah, Kurdistan Region, Iraq

Department of Accounting, Kurdistan Technical Institute, Sulaymaniah, Kurdistan Region, Iraq

\section{diary.ali@kti.edu.krd}

\section{Hawkar Anwer Hamad}

Department of Business and Administration, College of Administration and Economics, Lebanese French University, Erbil, Kurdistan Region, Iraq

hawker.anwar@lfu.edu.krd

\section{ARTICLE INFO}

\section{Article History:}

Received: 9/3/2021

Accepted: 22/4/2021

Published: Spring 2021

Keywords: Cash Flow Statement, Accounting information, Decision

\section{ABSTRACT}

This study aims to know the role of the cash flow statement in providing accounting information for the financial decisionmaking process in order to provide information on historical changes in cash for the institution by using cash flows that classify operation, investment, and financing flows.

In this research, we rely on the real data in the International Islamic Bank of Kurdistan in the year 2018 to reach concise results in the financial statements and the effect of decisionmaking to progress in this financial bank. The study results indicated that:

1- By preparing a list of cash flows, the unit can get an accurate view of its operating, financing, and investment operations. 
Doi:

2- That within the list of flows there is information on the aspects of receipts and cash payments, and this is useful for knowing the financial position of the economic unit.

10.25212/lfu.qzj.6.2.30

\section{INTRODUCTION}

A set of financial statements in economic units is prepared under the accounting principles of general acceptance and these lists have been designed to present the financial position of the enterprise on the specific date as well as the results of operations and cash flows for the period ending on that date and this includes information related to the facility's liquidity, and these lists are an important source To provide the information needed by external and internal parties, however, accountants generally use accounting concepts on an accrual basis as the best that can be used in presenting the financial position and business results (D Zhang, Z Tong, $Y$ Li). Through accounting on an accrual basis, we try to match efforts with achievements and we know that the activities you perform may not produce About cash flows inside or outside the same period in which these activities were carried out, (Tassadaq \& Malick, 2015).

\subsection{Research problem:}

The research problem arises from the failure to prepare a list of cash flows properly or was it not prepared within the basic financial statements and users of financial statements have what is important in preparing them, which negatively affects the provision of accounting information.

\subsection{Research objective:}

The most important objectives of the research are the following:

1- Clarify the importance of the statement of cash flows at the internal and external levels of the economic unit. 
2- A statement of the current cash flow deficiency, its ineffectiveness, and the need to prepare it properly.

\subsection{Research importance:}

The cash flow statement is one of the financial statements that must be prepared properly because most economic decisions depend on the information contained in that list and must be prepared in a way that meets the needs of the user's information.

\section{a. Research Hypothesis}

Based on the research problem and the answer to the questions raised in this research, the following hypotheses have been prepared:

The main hypothesis of the research (there is a correlation relationship between the information in cash flow statement and financial decision-making).

1- There is a correlation between transparency in financial reports and financial decision-making in the International Islamic Bank of Kurdistan Region of Iraq.

2- There is a correlation between all information that provided in statements and financial decision-making in the International Islamic Bank of Kurdistan Region of Iraq.

3- There is a correlation between operating/ financing information that provided in cash flow statement and financial decision-making in the International Islamic Bank of Kurdistan Region of Iraq.

\section{Literature Review}

\subsection{The concept of cash flow statement:}

The cash flow statement is one of the basic financial statements that the entity limits and aims to attempt to clarify how to obtain and use cash during the period. This list is seen as a tool to assess the company's position and to judge the efficiency of management performance (Alsohagy, 2013; AJ Mohammad, 2015). 
The statement of cash flows is the list to which we have cash receipts and cash payments that occurred during the period, that is, it shows us where the cash came from and where it was spent and explains to us the reasons for the change in the cash balance and this information cannot be reached using other financial statements (Jones, 2011; Sultan, et al., 2020).

\subsection{The objectives of the cash flow statement:}

The purpose of the Cash flow Statement is to shed light on the main activities that produced cash or that used cash during the period and indicate the effects on the total cash balance. This list is a powerful analytical tool used by management, investors, and lenders.

The statement of cash flows aims to achieve the following objectives:(Ismael, 2017; HA Abdullah, HG Awrahman)

1- Determine the amount of cash generated by the operation during the organized period to meet its obligations as they fall due, determine the value of the investment in a new plant, and determine the quality and extent of financing required to expand investment in long-term assets.

2- Predicting future cash flows, is cash, not accounting profit that is used to pay claims and distributions.

3- The management's decisions are evaluated, so if the managers make a good investment, then their business will flourish. As they make bad investment decisions, the facility management will suffer.

4- Determine the extent of the entity's ability to pay the dividends to the shareholders and pay the interest. The debt continued to the creditors. The shareholders are interested in obtaining dividends on their investments. Creditors are also interested in obtaining the benefits. 
5- The cash flow statement shows the relationship between the net income and the change in the cash available at the establishment. Usually, the cash and the net income move together. The high level of income leads to an increase in cash and vice versa, as the cash balance can decrease with the establishment achieving high profits.

\subsection{The form of the content of the cash flow statement:}

The cash flow statement is information for investors, creditors, and other users: (Andersson \& Kosted, 2016)

1- Cash and external flows from the three main activities of the project, operating investment, and financing.

2 - Reasons for the difference between net profit and accounting (in the application of the accrual basis and generally accepted accounting principles) and between net cash flows.

3- The effect of the flows on the financial position of the project: American Accounting Standard No. 95 has defined the form and content of the statement of cash flows, which must show internal and external cash flows from the following activities:

A - Operational activities: The cash flows are resulting from the main operations of the project from buying and selling commodities and all the normal operations that represent the operational cycle of the project.

B - Investment activities: The cash flows are resulting from the investment activities carried out by the legislator from buying and selling fixed assets, as well as investments in debts and ownership (stocks and bonds) of other companies.

C- Financing activities: The cash flows are resulting from the financing activities suspended for obtaining financing materials for the assets, whether from loans or the issuance of shares. The following table shows the most important elements that the list contains from the three main activities of the project: 


\subsection{Prepare a list of cash flows:}

To prepare a list of cash flows, you must obtain some information from the following sources: (Atrill, 2015)

1- Two consecutive general budgets:

Here we show the changes that occurred in the liabilities, assets, and property rights from the beginning of the period to the end of the period.

2- List of profits and losses:

From this list, we obtain whether the amount of cash flows from different activities during a specific period.

3- Some other information: -

It includes information on how to obtain cash and how to use it during a certain period.

The cash flow statement is prepared in two ways: (Elton, 2013)

\section{First: Indirect Method}

Under this method, the net cash flows of the operating activity are calculated by adjusting the net income (final product) of the income statement with other items.

The items that affected the net income extracted and did not affect the cash, so some call this Road and Methods of settlement, and include these items.

- Changes in items of current assets and liabilities that have a direct relationship with operational activities (such as the purchase and sale of goods and operating expenses). 
Items of non-monetary nature in the income statement, such as depreciation on tangible fixed assets and amortization expenses on intangible assets.

- Gains and losses related to the financing and investment activities of the entity, such as gains and losses from the sale of assets.

\section{Second: Direct Method}

The seventh criterion recommended establishments to follow the direct method when preparing the cash flow list, as this information would be useful when deciding future cash flows, in addition to adopting the same approach in presenting cash flows for different activities by comparing the cash inflows and outflows of cash. This method is called (Income statement) where the adjustment from the accrual basis to the cash basis includes all items of the income statement related to the operational activity (sales, sales costs, operating expenses).

\section{The trade-off between the direct and indirect method:}

The direct and indirect methods are alternatives to reach the net cash flows from the operational activities and the two methods lead to the same result, but they differ in the input used to reach this result directly. The income statement that was prepared based on the accounting accrual is transferred directly to the cash basis, while the method is not directed to the same result by adjusting (making adjustments) to the final net income number in the income statement.

\subsection{Uses of cash flow statement}

The cash flow statement and the utilization of it can be used by both the project's internal and external parties: (Nicoline, 2013)

A-Uses of administration:

The cash flow statement provides important information on important decisions of the administration previously taken, such as issuing capital shares or selling long-term bonds, and other information that cannot be obtained by other financial statements 
except in a simple way, and the list shows the cash flow from operating activities to finance all planned capital needs Internally, instead of the long-term external assumption of issuing stocks or bonds, and vice versa, if the list shows a cash deficit, the administration may use the list to determine the causes of occurrence such as splendor and by using the cash flow statement.

B- Uses of investors and creditors:

The cash flow statement helps investors, creditors and other entities determine the following:

1- The facility's ability to generate net positive cash flows.

2- The facility's ability to face its current obligations.

3- The facility's ability to pay dividends to shareholders.

4- Extent of the facility's need for external financing.

5- Reasons for the difference between net income, cash receipts, and accompanying cash payments.

\subsection{The nature of accounting information, its characteristics, and users}

\section{The nature of accounting information:}

One of the main characteristics of accounting information is that it is available to the public at a low cost - it is borne by those who want to obtain and use the information and the establishment bears the costs of producing and disseminating information. However, the publication of financial information with benefits and advantages achieved by the facilities and one of those advantages is to provide an opportunity for an organized capital market that can Enterprises during which from obtaining a capital increase, as it is in the interest of shareholders that there is a market for their shares and we find from the above that the establishments will be willing to bear the costs of publishing financial information as they did before the thirties, this will be 
done even without the presence of regulation and the difficulty in the reports The financial was in many cases very brief, not repeated, and as a result, (Ross, 2002).

\subsection{Characteristics of accounting information:}

The terms data and information are used most of the time as synonyms, but a distinction must be made between each of them. Data is a group related to events that can be recognized and measured, and these facts are often independent of each other. As for the information, it can be defined as collecting the relevant parts of each of the data. It is the quantitative information about the values that are processed and presented by the information systems in the external financial statements and operating reporting plans (Belkaoui, 2000).

Accounting information must have a set of characteristics, which are appropriate timing, accuracy, suitability, and reliability so that the information can be used effectively and these characteristics can be explained as follows:

\section{1- Timeliness}

The appropriate timing is not something that can be used to express whether a portion of the information has reached the decision-maker before making a specific decision. As for the appropriate timing feature (synchronization), it is intended to provide information promptly, but for the timing to be evaluated appropriately, a degree of portability must be studied. Decisions or actions that are taken by the user of the information are transformed, and accordingly, the timing of the information is not a simple matter that determines whether the information reached a user at the appropriate time, but instead there is a so-called degree of timing.

\section{2- Accuracy Precision}

The degree of accuracy of accounting information increases with the use of a sound data-processing system where human errors are greatly transmitted. Determining the value of information requires a description of the accuracy of this information. Of course, wrong or inaccurate information can result in inappropriate decisions with 
the possibility of improper distribution of costs, waste of time, and possibilities of growing losses (S Dhole, FA Gul, S Mishra, AM Pal).

\section{3- Adaptability}

Relevance is described as the original criterion for the value of the information. The information is appropriate if it satisfies the known or assumed needs of users.

\section{4- Trust Reliability}

The reliability of the information means the degree of objectivity contained therein which allows its users to reach the same results, in addition to an additional factor which is bias and the degree of trust can be increased by increasing the degree of objectivity reducing the degree of bias and then accountants must improve the degree of objectivity if bias does not increase at a faster rate than improvement in the degree of objectivity.

Therefore, the degree of trust $=$ the degree of objectivity + bias

Bias can produce not only the rules and their improper selection and application, but also the people who apply these rules.

\section{Chapter Three: Kurdistan International Islamic Bank}

A summary of the bank

The bank was established on 13/3/2005 and with subscribed and paid capital (400) billion Iraqi dinars, it is an Iraqi private joint-stock firm that practices banking, investment, and privatization activities, under the supervision and control of the Central Bank of Iraq, and all its activities are subject to the provisions of banks No. (94) for the year 2004, and the Banking Law Islamic No. (43) for the year 2015, the Companies Law No. (21) for the year 1997 amended, and the Anti-Money Laundering Law No. (39) for the year 2015, and the regulations, guidelines, instructions, and orders issued by the Central Bank of Iraq. In all its activities and operations, the bank adheres to the provisions of Islamic banking. 


\section{QALAAI ZANISTSCIENTIFIC JOURNAL \\ A Scientific Quarterly Refereed Journal Issued by Lebanese French University - Erbil, Kurdistan, Iraq}

Vol. (6), No (2), Spring 2021

ISSN 2518-6566 (Online) - ISSN 2518-6558 (Print)

Based on the vision of the pioneering bank and the established business strategies, the bank's administration has endeavored, through progressive goals and approved banking policies, to provide various banking services and products in response to customer requirements and their needs in terms of excellence, quality and quality while maintaining efficient performance and rationalizing expenditures according to a clear vision to finance the economic sectors and various activities with The link with basic goods and services and keeping abreast of technical developments and modern technologies to contribute to achieving economic development in the region in particular and Iraq in general as a strategic goal guided by the core values adopted as a guide for its work (trust - credibility, integrity and justice - transparency - continuous development - professional - customer service first) in addition to the regulations and decisions issued From specialized global bodies and bodies.

\section{Data Collection}

Kurdistan International Islamic Bank for Investment and Development

Consolidated Statement of Financial Position as of Dec.31, 2018

Table (1) (Balance sheet)

\begin{tabular}{|c|c|c|c|}
\hline Assets & Notes & $\begin{array}{c}31 / 12 / 2018 \\
\text { IQD } 1000\end{array}$ & $\begin{array}{c}31 / 12 / 2017 \\
\text { IQD 1000 }\end{array}$ \\
\hline Cash and Balances with central Bank of Iraq & 4 & $576,807,014$ & $558,126,218$ \\
\hline Balances with other Banks & 5 & $635,435,086$ & $447,063,067$ \\
\hline Islamic Financing Assets (net) & 6 & $1,861,424$ & $2,841,178$ \\
\hline Investments (net) & 7 & $2,732,511$ & $11,681,096$ \\
\hline Other Assets (net) & 8 & $3,730,026$ & $2,591,229$ \\
\hline Intangibles & 9 & $3,229,951$ & $1,645,394$ \\
\hline Property, plants and Equipment (net) & 10 & $37,659,376$ & $40,645,625$ \\
\hline Project in Progress & 11 & $1,504,446$ & $3,018,299$ \\
\hline Total Assets & & $\mathbf{1 , 2 6 2 , 9 5 9 , 8 3 4}$ & $\mathbf{1 , 0 6 7 , 6 1 2 , 8 3 4}$ \\
\hline Liabilities \& Owners Equity & & & \\
\hline Liabilities & & & \\
\hline Bank' Deposits & 12 & 396,072 & 525,959 \\
\hline Customers' Deposits & 13 & $549,227,848$ & $310,260,370$ \\
\hline Deposits on Banking \& Financial Operations & 14 & $\mathbf{2 5 , 3 0 7 , 4 0 9}$ & $\mathbf{6 4 , 6 5 4 , 6 1 9}$ \\
\hline
\end{tabular}




\section{QALAAI ZANISTSCIENTIFIC JOURNAL}

A Scientific Quarterly Refereed Journal Issued by Lebanese French University - Erbil, Kurdistan, Iraq

Vol. (6), No (2), Spring 2021

ISSN 2518-6566 (Online) - ISSN 2518-6558 (Print)

\begin{tabular}{|c|c|c|c|}
\hline Other Liabilities & 15 & $2,764,536$ & $15,377,412$ \\
\hline CBI Financing & 16 & $2,100,000$ & $1,500,000$ \\
\hline Charity Account & 17 & & 1,682 \\
\hline Provisions & 18 & $64,936,548$ & $63,672,649$ \\
\hline Insurance Contracts Liabilities & 19 & $1,744,742$ & $1,648,771$ \\
\hline Total Liabilities & & $\mathbf{6 4 6 , 4 7 7 , 1 5 5}$ & $\mathbf{4 5 7 , 6 4 1 , 4 6 2}$ \\
\hline Equity & & & \\
\hline Capital & & $400,000,000$ & $\mathbf{4 0 0 , 0 0 0 , 0 0 0}$ \\
\hline Reserve & & $132,312,226$ & $129,438,134$ \\
\hline Retained earnings & & $\mathbf{7 3 , 0 0 5 , 6 6 0}$ & $69,449,875$ \\
\hline Minority Interests & & $11,164,793$ & $11,082,635$ \\
\hline Total Equity & & $\mathbf{6 1 6 , 4 8 2 , 6 7 9}$ & $\mathbf{6 0 9 , 9 7 0 , 6 4 4}$ \\
\hline Total Liabilities \& Equity & & $\mathbf{1 , 2 6 2 , 9 5 9 , 8 3 4}$ & $\mathbf{1 , 0 6 7 , 6 1 2 , 1 0 6}$ \\
\hline
\end{tabular}

Kurdistan International Islamic Bank for Investment and Development Consolidated Statement of Profit or Loss and Other Comprehensive Income for the financial year ended Dec. 31/2018

Table (2): (Income Statement)

\begin{tabular}{|c|c|c|c|}
\hline & Notes & $\begin{array}{c}2018 \\
\text { IQD } 1000\end{array}$ & $\begin{array}{c}2017 \\
\text { IQD } 1000\end{array}$ \\
\hline Operating Income & & & \\
\hline Islamic Finance Income & 20 & 762,373 & $2,457,615$ \\
\hline Fees \& Commission Income (net) & 22 & $11,038,196$ & $\mathbf{2 9 , 5 8 5 , 1 9 1}$ \\
\hline Insurance Operations Income (net) & 23 & $(435,246)$ & 82,182 \\
\hline Investment Income & 21 & 232,454 & 186,078 \\
\hline Income from Trade of Foreign Exchange & 24 & $15,299,706$ & $\mathbf{2 9 , 7 3 7 , 2 3 0}$ \\
\hline Misc. Income & 25 & $11,184,865$ & $\mathbf{2 1 , 0 0 5 , 9 4 7}$ \\
\hline Total Operating Income & & $\mathbf{3 8 , 0 8 2 , 3 4 8}$ & $\mathbf{8 3 , 0 5 4 , 2 4 3}$ \\
\hline Salaries and Related Charges & 26 & $9,050,413$ & $9,760,106$ \\
\hline Administrative \& General Expenses & 27 & $7,986,798$ & $11,308,252$ \\
\hline Depreciation \& Amortization & $9 / 10$ & $4,286,491$ & $3,844,008$ \\
\hline Taxes \& duties & 28 & 98,628 & 160,301 \\
\hline Allowance on Foreign ex. Fluctuations & 18 & 0 & 433,247 \\
\hline Other Expenses & 29 & $4,061,740$ & $3,827,615$ \\
\hline Total Expenses & & $\mathbf{2 5 , 4 8 4 , 0 7 0}$ & $\mathbf{2 9 , 3 3 3 , 5 2 9}$ \\
\hline Profit (Loss) before distribution to deposits & & $\mathbf{1 2 , 5 9 8 , 2 7 8}$ & $\mathbf{5 3 , 7 2 0 , 7 1 4}$ \\
\hline Minus. Distribution to Deposits & & $\mathbf{( 4 , 2 1 9 , 5 6 0 )}$ & $4,757,026$ \\
\hline Profit (Loss) Before Tax & & $\mathbf{8 , 3 7 8 , 7 1 8}$ & $\mathbf{4 8 , 9 6 3 , 6 8 8}$ \\
\hline Minus. Income Tax & 18 & $(1,261,336)$ & $(\mathbf{7 , 3 5 6 , 0 9 8 )}$ \\
\hline
\end{tabular}




\section{QALAAI ZANISTSCIENTIFIC JOURNAL}

A Scientific Quarterly Refereed Journal Issued by Lebanese French University - Erbil, Kurdistan, Iraq

Vol. (6), No (2), Spring 2021

ISSN 2518-6566 (Online) - ISSN 2518-6558 (Print)

\begin{tabular}{|c|c|c|c|}
\hline Profit (Loss) After Tax & $\mathbf{7 , 1 1 7 , 3 8 2}$ & $\mathbf{4 1 , 6 0 7 , 5 9 0}$ \\
\hline Other Comprehensive Income & & & \\
\hline Comprehensive Income for the Year & & $\mathbf{7 , 1 1 7 , 3 8 2}$ & $\mathbf{4 1 , 6 0 7 , 5 9 0}$ \\
\hline
\end{tabular}

\section{Comprehensive Income Distributed as Follows:}

\begin{tabular}{|c|c|c|}
\hline & $\begin{array}{c}\mathbf{2 0 1 8} \\
\text { IQD 1000 }\end{array}$ & $\begin{array}{c}\mathbf{2 0 1 7} \\
\text { IQD 1000 }\end{array}$ \\
\hline Expansion Reserve & $3,459,585$ & $20,747,590$ \\
\hline Capital Reserve & 345,959 & $4,149,518$ \\
\hline General Reserve & 31,991 & 9,469 \\
\hline Retained Earnings & $3,195,785$ & $16,649,543$ \\
\hline Minority Interests & 82,159 & 51,470 \\
\hline Total & $\mathbf{7 , 1 1 7 , 3 8 2}$ & $\mathbf{4 1 , 6 0 7 , 5 9 0}$ \\
\hline
\end{tabular}

Table (3): Kurdistan International Islamic Bank for Investment and Development

Consolidated Statement of Cash Flows for the Year ended Dec. 31/2018

Table (4)

\begin{tabular}{|c|l|c|c|}
\hline & Notes & $\begin{array}{c}\mathbf{2 0 1 8} \\
\text { IQD 1000 }\end{array}$ & $\begin{array}{c}\mathbf{2 0 1 7} \\
\text { IQD 1000 }\end{array}$ \\
\hline Cash Flows for the year & & & \\
\hline Profit (Loss) for the year & & $\mathbf{7 , 1 1 7 , 3 8 2}$ & $\mathbf{4 1 , 6 0 7 , 5 9 0}$ \\
\hline Adjustment for : & & & \\
\hline Depreciation \& Amortization for the year & $9 / 10$ & $4,286,491$ & $3,844,008$ \\
\hline Minus: Depreciation of Disposals & 10 & $(1,476,620)$ & $(116,245)$ \\
\hline Net impairment of credit facilities & 6 & $(12,169,420)$ & $(16,893,179)$ \\
\hline Income Tax Provision & 18 & $1,261,336$ & $\mathbf{7 , 3 5 6 , 0 9 8}$ \\
\hline Other Provisions & 18 & 9,278 & $(2,044,329)$ \\
\hline Sub-Total & & $\mathbf{( 9 7 1 , 5 5 3 )}$ & $\mathbf{3 3 , 7 5 3 , 9 4 3}$ \\
\hline Change in operating assets \& Liabilities & & & \\
\hline Islamic Financing & 6 & $13,149,174$ & $33,921,124$ \\
\hline Other Assets & 8 & $(1,139,095)$ & $1,134,271$ \\
\hline Bank's Deposits & 12 & $(129,887)$ & 61,268 \\
\hline Customer's Deposits & 13 & $238,967,478$ & $37,673,125$ \\
\hline Other Liabilities & 14 & $(39,347,210)$ & $(1,322,745)$ \\
\hline Charity & 15 & $(12,619,592)$ & $10,587,835$ \\
\hline Deposits on Banking \& Financial Operations & 17 & $(1,682)$ & $(1,109,979)$ \\
\hline Insurance Contracts Liabilities & 19 & 95,971 & 0 \\
\hline Sub-Total & & $\mathbf{1 9 8 , 9 7 5 , 1 5 7}$ & $\mathbf{8 0 , 9 4 4 , 8 9 9}$ \\
\hline Net Cash Flows from Operating Activities & & $\mathbf{1 9 8 , 0 0 3 , 6 0 4}$ & $\mathbf{1 1 4 , 6 9 8 , 8 4 2}$ \\
\hline
\end{tabular}




\section{QALAAI ZANISTSCIENTIFIC JOURNAL}

A Scientific Quarterly Refereed Journal Issued by Lebanese French University - Erbil, Kurdistan, Iraq

Vol. (6), No (2), Spring 2021

ISSN 2518-6566 (Online) - ISSN 2518-6558 (Print)

\begin{tabular}{|c|l|c|c|}
\hline Cash Flows from Investing Activities & & & \\
\hline Acquisition / Disposal of Fixed Assets & 10 & $1,209,586$ & $(4,608,648)$ \\
\hline Acquisition / Sale of Investments & 7 & $8,948,585$ & $(8,383,242)$ \\
\hline Intangibles & 9 & $(2,617,765)$ & $(1,647,056)$ \\
\hline Projects in Progress & 11 & $1,513,853$ & $2,612,753$ \\
\hline Net Cash Flow from Investing Activities & & $\mathbf{9 , 0 5 4 , 2 5 9}$ & $\mathbf{( 1 2 , 0 2 6 , 1 9 3 )}$ \\
\hline Cash Flows from Financing Activities & & & \\
\hline Finance Received from CBI & 16 & 600,000 & $(350,000)$ \\
\hline Reserves & & $(509,375)$ & \\
\hline Net Cash Flow from Financing Activities & & $\mathbf{( 5 , 3 4 6 )}$ & $\mathbf{( 3 5 0 , 0 0 0 )}$ \\
\hline Net Cash Flows & & $\mathbf{2 0 7 , 0 5 2 , 5 1 7}$ & $\mathbf{1 0 2 , 3 2 2 , 6 4 9}$ \\
\hline Cash and its Equivalent at Jan. 1 & $\mathbf{4 / 5}$ & $\mathbf{1 , 0 0 5 , 1 8 9 , 5 8 3}$ & $\mathbf{9 0 2 , 8 6 6 , 6 3 6}$ \\
\hline Cash and its Equivalent at Dec. 31 & $\mathbf{4 / 5}$ & $\mathbf{1 , 2 1 2 , 2 4 2 , 1 0 0}$ & $\mathbf{1 , 0 0 5 , 1 8 9 , 2 8}$ \\
\hline
\end{tabular}

\section{Discussion:}

An effort was focused in this field to ensure compliance with the requirements set out in the IFRS 10 standard for financial data standardization, as standardization under this standard requires the investor to have control over the investor, and the standard sets three basic conditions for achieving control, namely: authority over the investor With him, the investor is exposed to or has rights to variable returns through his relationship with the investor, and the investor's ability to use his authority over the investor to influence the value of the returns. A cash account with external banks whose balance as of 12/31/2018 represents about (203) billion dinars' balances of accounts exchanged with external correspondent banks and financial institutions that the bank has dealings with. The risk to these accounts comes from not completing the matches and adjustments on time, which leads to the bank's rights being involved in the bank is charged with wrong entries. An effort has been made to verify the completion of matches and to address the accumulated arrears from previous years. Although the bank has made remarkable progress in this area, it still requires extensive efforts to liquidate the arrears. Operating risks come from potential losses as a result of the failure of the bank's internal operations, systems, or management, or as a result of internal and external events and cases of fraud and fraud, that the Basel A / first pillar standards and the $\mathrm{CBI}$ instructions require the bank to establish a framework that ensures oversight of these risks and their management to what Write 
down the appetite for the risks involved, as well as monitor, record, and address related events. It also requires that the bank measure these risks (the approved method is the basic indicator method which means taking $15 \%$ of the profit rate of operations for the previous three years) and adding it to the denominator of the capital adequacy ratio.

\section{Conclusion:}

The financial statements are based on the inputs of the accounting system, which consist of various data concerning accounting that can be obtained from the accounting records and books used in any economic unit. That is why the cash flow statement was considered one of the basic lists, due to the importance of the information provided by making decisions. By preparing a list of cash flows, the unit can accurately view its operational, financing, and investment operations. Inside the list of flows has information on the aspects of cash receipts and payments, and this is useful for learning about the financial position of the economic unit. The preparation of the statement of cash flows by the accounting standards and rules is done in two ways: the direct method. The indirect method the direct method is easy to prepare and its concept more than the indirect method, especially for users who do not know accounting knowledge.

\section{Recommendation:}

The necessity of preparing economic units for all basic financial statements. The need to prepare a list of cash flows because it provides useful information, especially on operational, financing, and investment matters. It must be taken into consideration that the financial statements in general and the cash flow statements, in particular, are prepared and relied upon by external parties. The accounting information provided by the accounting system must contain a set of characteristics (major and minor) of accounting information. The necessity of relying on the information provided by the cash flow statement in taking many decisions and evaluating the efficiency of the economic unit in the field of future cash flows and providing liquidity the direct method is preferred, and this is because it provides full, detailed and clear 


\section{QALAAI ZANISTSCIENTIFIC JOURNAL}

A Scientific Quarterly Refereed Journal Issued by Lebanese French University - Erbil, Kurdistan, Iraq

Vol. (6), No (2), Spring 2021

ISSN 2518-6566 (Online) - ISSN 2518-6558 (Print)

information about cash inflows (received from customers) and outflows (cash payments on the cost of goods sold).

\section{REFERENCES:}

Alsohagy, M. (2013, March). The credibility of Financial Reporting Communication Between Investors and Management: An Exploratory Study. Business Review, 2, 61-68.

Andersson, D., \& Kosted, J. (2016). Financial Credibility Financial Constraints and rule of law. 1- 94.

Atrill, p. m. (2015). accounting and finance for non specialists, 9 edition paperback playouth person.

Abdullah, H. A., Awrahman, H. G., \& Omer, H. A. (2021). Effect of Working Capital

Management on The Financial Performance of Banks: An Empirical Analysis for Banks Listed on The Iraq Stock Exchange. QALAAI ZANIST SCIENTIFIC JOURNAL, 6(1), 429-456.

Belkaoui, Ahmed R., (2000), Accounting Theory, 4th ed., Thomson Learning.

Elton, e. g. (2013). Elton, E.J., Gruber, M.J., Brow. Investment Analysis, 8th Edition. Paperback: John Wiley \& Sons, 2010.

Dhole, S., Gul, F. A., Mishra, S., \& Pal, A. M. (2021). The joint information role of analysts' cash flow and earnings forecasts. Accounting \& Finance, 61(1), 499-541.

Ismael, A. Y. (2017). The Impact of Creative Accounting Techniques on the Reliability of Financial Reporting with Particular Reference to Saudi. International Journal of Economics and Financial Issues, 2017, 7(2), 283-291., 7(2), 283-291.

Jones, M. J. (2011). investigate the accounts of companies so that stocks and shares can be priced efficiently. In order to do this effectively they need to be able to spot and detect creative accounting and, indeed, fraud. presented analysts with a set of doctored accounts.

Mohammad, A. J. (2015). Human capital disclosures: Evidence from Kurdistan. European Journal of Accounting Auditing and Finance Research, 3(3), 21-31.

Ross, Stephen A., \& others, 2002, Corporate finance, 6th ed., McGraw-Hill Irwin. 


\section{QALAAI ZANISTSCIENTIFIC JOURNAL}

A Scientific Quarterly Refereed Journal Issued by Lebanese French University - Erbil, Kurdistan, Iraq

Vol. (6), No (2), Spring 2021

ISSN 2518-6566 (Online) - ISSN 2518-6558 (Print)

Tassadaq, F., \& Malick, Q. A. (2015). Creative accounting and financial reporting model development and empirical testing. econjournals, 5(2), 544, 550.

Zhang, D., Tong, Z., \& Li, Y. (2020). The role of cash holding towards cleaner production in China's manufacturing sectors: A financial constraint perspective. Journal of Cleaner Production, 245, 118875.

\section{رِّولّى ليستى كُوزمهى يارهى نهختينهيى (قائمه التدفقات النقديه) به به مهبهستى بهدهت هيّنانى زانيارى زميّريارى تايبهت به برياردان}

\section{يـوخـتهـ:}

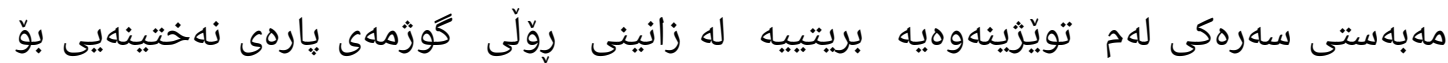

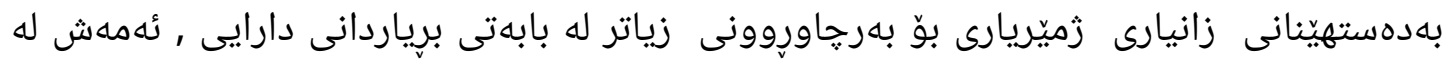
ئهنجامى بهدهستهيّنانى زانيارى سهبارهت بهو گَّورانكاريانهى بهسهر يارهى دامهزراوهكهدا هاتووه له

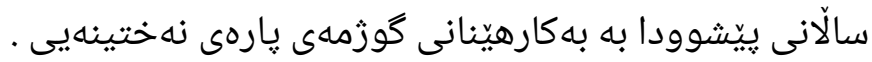
لهم تويّزينهوهيهدا يشتمان بهستوه به زانيارى و داتا راست و دروستهكانى بانكى كوردستانى اسلامى نيّودهولّهتى له سالّى 2018 بوّ كهيشتن به زانيارييه داراييهكان و كاريكهرى برِياردان لهسهر يِيشكهوتنى ئهم بانكه .

دهرئهنجامهكانى تويّزينهوهكه دوو خالّى گرنخمان بوّ روون دهكاتهوه :

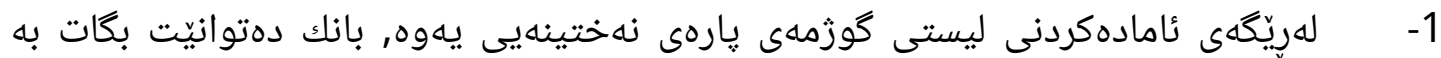
بهرجاو روونيهكى تهواو لهسهر كاروجالاكيه كانى بهكهرخستن و يارهداركردن و وهبهرهيّنان.

2- ههر لهريّكهى ليستى گوزمهى يارهى نهختينهيى يهوه دهتوانين زانيارى تهواو بهدهست بهيّنين لهسهر برِى يارهى وهركيراو و برِى يارهى خهرج كراو ,كه ئهمش كرنكيهكى زوّرى ههيه بوّ زانينى دوّخى دارايى بانكهكه . 


\section{QALAAI ZANISTSCIENTIFIC JOURNAL}

A Scientific Quarterly Refereed Journal Issued by Lebanese French University - Erbil, Kurdistan, Iraq

Vol. (6), No (2), Spring 2021

ISSN 2518-6566 (Online) - ISSN 2518-6558 (Print)

دور قائمة التدفقات النقية لتوفير المعلومات المحاسبية لعملية اتخاذ القرار (اين المدة الزمنية للبحث وكذلك الجهة التي طلق الجانب العلمي للبحث فيها)

(الملخص:

الهدف من هذه الدراسة هو معرفة دور التدفقات النقدية في توفير المعلومات المحاسبية لعملية اتخاذ القرار المالي

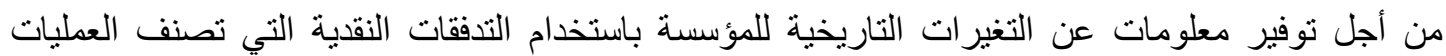
والاستثمار ات و التمويل لهذه المؤسية.

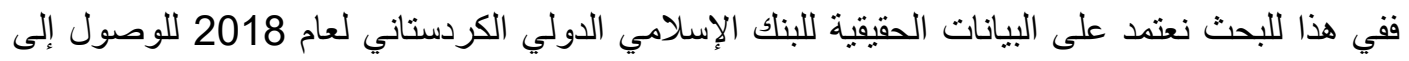

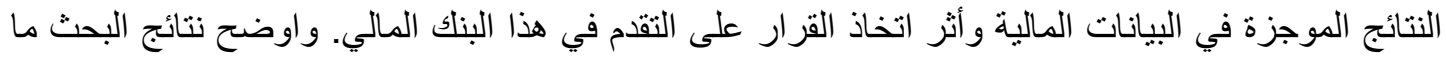
يلي:

1- من خلال إعداد قائمة بالتدفقات النقدية ، يمكن للوحدة الحصول على رؤية دقيقة لعمليات التشغيل و التمويل و والاستثمار.

2- يوجد ضمن قائمة التدفقات معلومات عن جو انب الإيصالات و المدفو عات النقدية ، و هذا مفيد لمعرفة الوضع المالي للوحدة الاقتصادية. 